\title{
Sleep deprivation affects inflammatory marker expression in adipose tissue
}

\author{
José C Rosa Neto ${ }^{1 *}$, Fábio S Lira ${ }^{1}$, Daniel P Venancio ${ }^{2}$, Cláudio A Cunha ${ }^{1}$, Lila M Oyama ${ }^{1}$, Gustavo D Pimentel', \\ Sérgio Tufik ${ }^{2,3}$, Cláudia M Oller do Nascimento ${ }^{1}$, Ronaldo VT Santos ${ }^{4}$, Marco T de Mello ${ }^{2,3}$
}

\begin{abstract}
Sleep deprivation has been shown to increase inflammatory markers in rat sera and peripheral blood mononuclear cells. Inflammation is a condition associated with pathologies such as obesity, cancer, and cardiovascular diseases. We investigated changes in the pro and anti-inflammatory cytokines and adipokines in different depots of white adipose tissue in rats. We also assessed lipid profiles and serum levels of corticosterone, leptin, and adiponectin after 96 hours of sleep deprivation.
\end{abstract}

Methods: The study consisted of two groups: a control (C) group and a paradoxical sleep deprivation by $96 \mathrm{~h}$ (PSD) group. Ten rats were randomly assigned to either the control group (C) or the PSD. Mesenteric (MEAT) and retroperitoneal (RPAT) adipose tissue, liver and serum were collected following completion of the PSD protocol. Levels of interleukin (IL)-6, interleukin (IL)-10 and tumour necrosis factor (TNF)- $\alpha$ were analysed in MEAT and RPAT, and leptin, adiponectin, glucose, corticosterone and lipid profile levels were analysed in serum.

Results: IL-6 levels were elevated in RPAT but remained unchanged in MEAT after PSD. IL-10 protein concentration was not altered in either depot, and TNF- $\alpha$ levels decreased in MEAT. Glucose, triglycerides (TG), VLDL and leptin decreased in serum after 96 hours of PSD; adiponectin was not altered and corticosterone was increased.

Conclusion: PSD decreased fat mass and may modulate the cytokine content in different depots of adipose tissue. The inflammatory response was diminished in both depots of adipose tissue, with increased IL-6 levels in RPAT and decreased TNF- $\alpha$ protein concentrations in MEAT and increased levels of corticosterone in serum.

\section{Introduction}

A large body of evidence has shown that prolonged paradoxical sleep deprivation (PSD) leads to a reduction in body mass, elevated energy metabolism, changes in circulating hormones, loss of immune integrity, and other disorders [1,2]. Moreover, sleep deprivation has produced hyperphagia, weight loss, increased energy expenditure, increased in plasma catecholamine concentration, hypothyroidism, reduction in core temperature, deterioration in physical appearance [3], and reduced levels of anabolic hormones [4]. Importantly, as the occurrence of sleep disturbances increases in modern lifestyles, so too does the risk of cardiovascular disease [5].

PSD induces an inflammatory response with increases in serum pro-inflammatory cytokines [6,7]. Seventy-two hours of PSD increased TNF- $\alpha$, IL-6, IL- $1 \alpha$ and IL-1 $\beta$

\footnotetext{
* Correspondence: josecesar23@hotmail.com

'Departmento de Fisiologia da Nutrição, Universidade Federal de São Paulo (UNIFESP)-São Paulo/SP, Brazil

Full list of author information is available at the end of the article
}

levels in the sera of rats [7]. C-reactive protein and IL-6 were increased in humans after sleep deprivation [8]. Additionally, a recent study showed that sleep restriction to $50 \%$ of the time habitually spent sleeping, over a 10 day period, induced significant increases in IL-6 levels in serum [9]. Chronic elevation of inflammatory proteins can contribute to health problems including cardiovascular, endocrine, mood, and sleep disorders [10]

Moreover, subjects with sleep loss showed an increase in nuclear factor NF- $\kappa$ B DNA binding in peripheral blood mononuclear cells [11]. NF- $\kappa \mathrm{B}$ activation is thought to contribute to the pathophysiology of diseases such as Diabetes mellitus, cardiovascular disease, and atherosclerosis [12].

During situations that induce stress, like exhaustive exercise and cancer, adipose tissue shows increased expression of cytokines, which act both locally and distally and have autocrine, paracrine and endocrine effects $[13,14]$. The physiology, metabolism and function of white adipose tissue vary in a depot-specific manner [15]. 
Therefore, marked differences in gene expression amongst depots are reported for both rodents [16] and humans [17]; cytokine secretion is also heterogeneous. Adipose tissue is responsible for $30 \%$ of circulating IL-6 and TNF- $\alpha$ at rest [18], and in some diseases (e.g., obesity, Diabetes mellitus), this tissue contributes to systemic levels at even greater percentages [17].

The aim of this study was to examine the effects of PSD at 96 hours on the expression of pro-(TNF- $\alpha$ and IL- 6 ) and anti-inflammatory (IL-10) cytokines in different depots of adipose tissue, as well as on the serum levels of the adipokines leptin and adiponectin.

\section{Methods}

\section{Animals}

Male Wistar rats, aged 3 months and weighing 300-350 g at the beginning of the experiment, were obtained from the Instituto Nacional de Farmacologia (INFAR) colony at UNIFESP. The rats were housed inside standard polypropylene cages in a temperature-controlled $\left(23.1^{\circ} \mathrm{C}\right)$ room with a 12:12 h light-dark cycle (lights on at 06:00 hours). All procedures used in the present study complied according to the guide for care and use of laboratory animals, and the experimental protocol was approved by the UNIFESP Ethical Committee (0876/09).

\section{Paradoxical sleep deprivation procedure}

The experimental groups were submitted to a single platform sleep deprivation method. The single platform-onwater (flower pot) method is extensively used for depriving paradoxical sleep. This technique involves placing the animal on a narrow circular platform $(10 \mathrm{~cm}$ in height and $6.5 \mathrm{~cm}$ in diameter) placed inside a chamber $(23 \times 23 \times$ $35 \mathrm{~cm}$ ) filled with water to within $1 \mathrm{~cm}$ of their upper surface over a period of $96 \mathrm{~h}$. At the onset of each paradoxical sleep episode, the animal experiences a loss of muscle tone and falls into the water, thus being awakened. The narrow platform procedure caused complete and selective loss of PS during all four days. Food and water were provided ad libitum by placing chow pellets and water bottles on a grid located on top of the chamber. The base of the feeder was adapted with a plate to prevent pieces of chow from falling into the water. The water in the chamber was changed daily throughout the PSD period. Control rats were placed inside the water chamber, but, instead of water, the chamber was filled with sawdust.

\section{Hormonal assay}

After the PSD period, the rats were brought to an adjacent room and decapitated between 09:00 a.m. and 12:00 p.m. The control group rats were euthanised at the same time as the experimental group, by euthanised on the first day of the experimental procedure. Blood was collected in glass tubes and centrifuged to obtain samples of serum or plasma. Samples were maintained at $-20^{\circ} \mathrm{C}$ until assay. Corticosterone concentrations were assayed by a double antibody RIA method designed specifically for rodents, using a commercial kit (ICN Biomedicals, Costa Mesa, CA, USA). The sensitivity of the assay is $0.25 \mathrm{ng}$ $\mathrm{dL}^{-1}$. Serum leptin and adiponectin were quantified using specific enzyme immunoassays (Genese ${ }^{\ominus}$, Brazil), following the manufacturer's instructions.

Following sacrifice, mesenteric (MEAT) and retroperitoneal (RPAT) white adipose tissue samples were removed, snap frozen in liquid nitrogen, and stored at $-80^{\circ} \mathrm{C}$.

\section{Lipid profile}

Triglycerides (TG), HDL-cholesterol, and total cholesterol were assessed through commercial enzymatic kits (Labtest ${ }^{\circ}$, São Paulo, Brazil). VLDL and LDL-cholesterol as well as TG hepatic content were calculated according to previously reported methods $[19,20]$. Plasma glucose concentration was measured using the enzymatic colorimetric method (Biotécnica, São Paulo, Brazil).

\section{TNF- $\alpha$, IL-10, IL-6, protein level determinations}

Frozen tissues (0.1-0.3 g) were homogenised in RIPA buffer $(0.625 \%$ Nonidet P-40, $0.625 \%$ sodium deoxycholate, $6.25 \mathrm{mM}$ sodium phosphate, and $1 \mathrm{mM}$ ethylene-diamine tetraacetic acid at $\mathrm{pH} 7.4$ ) containing $10 \mu \mathrm{g} / \mathrm{ml}$ of a protease inhibitor cocktail (Sigma-Aldrich, St. Louis, Missouri). Homogenates were centrifuged at 12,000 $\times g$ for $10 \mathrm{~min}$ at $4^{\circ} \mathrm{C}$, the supernatant was stored, and the protein concentration was determined using the Bradford assay (Bio-Rad, Hercules, California) with bovine serum albumin as a reference. Quantitative assessment of TNFa, IL- 6 and IL-10 was carried out by ELISA (DuoSet ELISA, R\&D Systems, Minneapolis, MN). For the TNF- $\alpha$ (DY510), IL-6 (DY506) and IL-10 (DY522) assays, the sensitivity was found to be $5.0 \mathrm{pg} / \mathrm{ml}$ Intra- and interassay variability of the TNF- $\alpha$ and IL-6 kits was $2.7-5.2 \%$ and $4.9-9.5 \%$, respectively. Assay sensitivity for IL-10 was $10 \mathrm{pg} / \mathrm{ml}$. The intra-assay variability of the IL-10 kit was $2.0-4.2 \%$, and its inter-assay variability was $3.3-6.4 \%$. All samples were run as duplicates, and the mean values were reported.

\section{Statistical analysis}

All data are expressed as mean \pm standard deviation (SD). The Student's $t$-test was used to evaluate the statistical significance of differences between means. P-values of less than 0.05 were considered statistically significant.

\section{Results}

Ten rats were randomly assigned to either the control group $(C)(N=5)$ or the 96 hour (PSD) group $(\mathrm{N}=5)$. PSD treatment decreased weight of RPAT $(-65.1 \%)$, 
MEAT (-68.3\%) and liver (-35\%). Fat content in liver tissue was decreased in the PSD group as compared to the C group (52.1\%) (Table 1).

\section{Metabolic profile}

Plasma levels of glucose (decrease 13.4\% in the PSD group as compared to the control group), TG (-34.2\%), and VLDL (-35.1\%) were decreased in PSD. However, plasma levels of cholesterol, LDL cholesterol and HDL cholesterol did not differ between groups (Figure 1).

\section{Hormonal concentrations}

Corticosterone concentrations increased at $96 \mathrm{~h}$ of PSD $(+337.13 \%)$ with respect to the control group (Figure 2).

Leptin $(-91,7 \%)$ was decreased and adiponectin plasma levels were not altered between groups (Figure 3).

\section{Cytokine concentration}

IL-6 protein content was increased in RPAT (+81,3\%), but not altered in MEAT after sleep deprivation (Figure 4). IL-10 protein content was not altered in either depot. TNF- $\alpha$ protein content was decreased in MEAT $(-25 \%)$, but it was unchanged in RPAT in the PSD group as compared to the $\mathrm{C}$ group (Figure 4).

\section{Discussion}

In this study, cytokines in adipose tissue were regulated after 96 hours of PSD in rats. In addition, the responses in different depots of adipose tissue were heterogeneous, as IL-6 levels increased in RPAT, but TNF- $\alpha$ concentrations decreased in MEAT. Moreover, lipid profiles were also altered by sleep deprivation. Corticosterone levels were greatly increased and leptin levels were dramatically decreased in serum after 96 hours of PSD.

A general reduction in the amount of time spent sleeping, as well as a greater frequency of more acute episodes of sleep deprivation, have become endemic conditions in modern society. This fact is highlighted by findings reported in the current literature, which identify important associations between sleep loss and alterations in nutritional aspects and metabolism [21-23]. Ninety-six hours of sleep deprivation in rats resulted in decreased plasma levels of glucose, TG and VLDL. This effect upon lipid metabolism is in agreement with a previous report [5].

Alterations in sleep duration influence control of food intake $[24,25]$. Many studies have demonstrated that
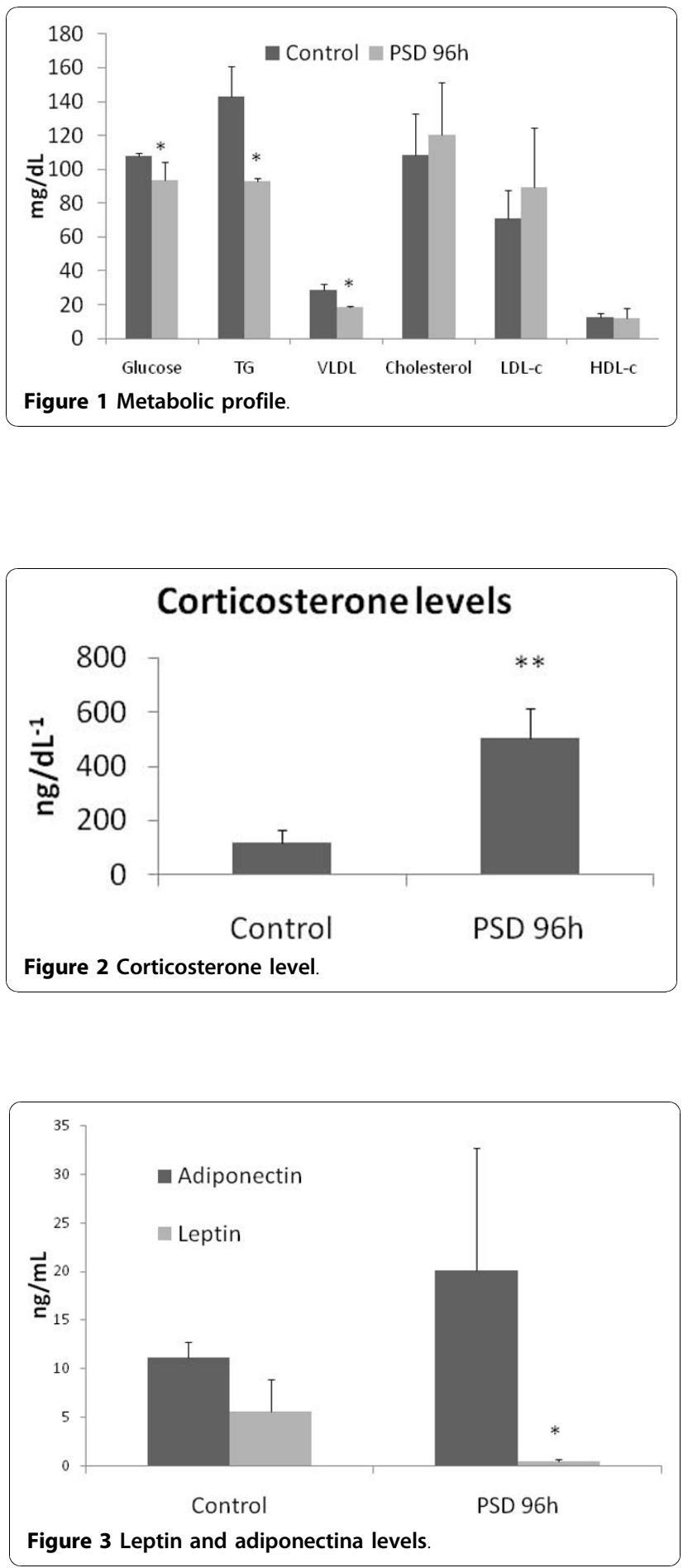

Table 1 Weight of RPAT, MEAT, liver and Fat content in liver

\begin{tabular}{llll}
\hline Groups & Liver weight $(\mathbf{g})$ & $\begin{array}{l}\text { Hepatic TAG } \\
\text { (mg TAG/100 } \mathbf{~ m g ~ l i v e r ) ~}\end{array}$ & MEAT weight (g) \\
\hline Control & $11.56 \pm 1.47$ & $22.03 \pm 8.35$ & $1.63 \pm 0.50$ \\
PSD96h & $7.55 \pm 0.69^{*}$ & $10.76 \pm 6.28$ & $0.57 \pm 0.21^{*}$ \\
\hline
\end{tabular}

Results are expressed as mean value \pm SE. $p<0.05^{*}$, significantly different from control values. 


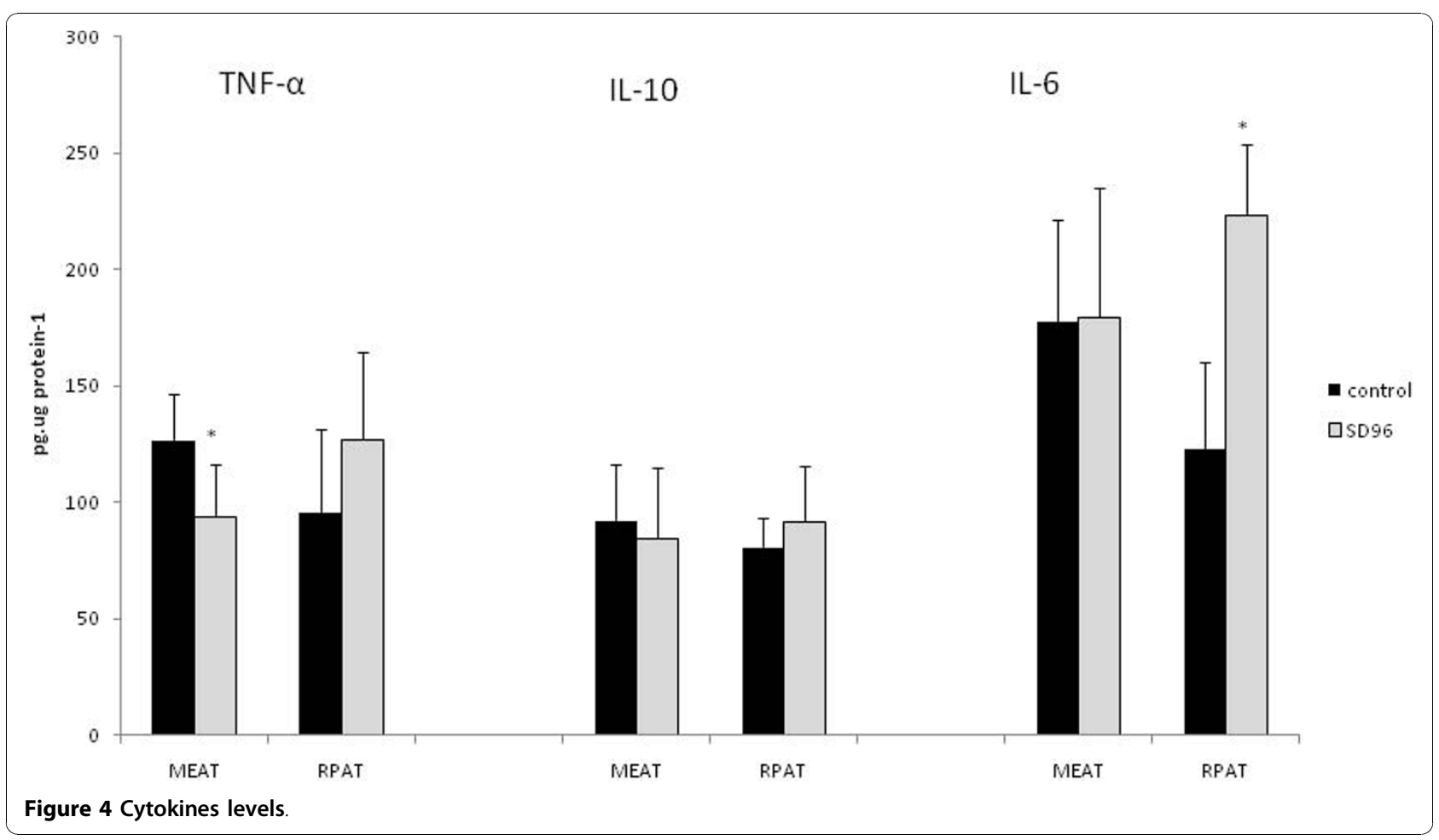

sleep loss increases food intake, while decreasing body weight $[1,3,26]$. Increased food intake is associated with an imbalance in the anorexigenic hormone, leptin [27-29], and an increase in the orexigenic hormone ghrelin $[29,30]$. In our study, serum concentrations of leptin decreased dramatically after 96 hours of PSD sleep deprivation, associated with a reduction in adipose fat mass. Koban and Swinson [2] showed that leptin decreased after sleep deprivation and remained low following twenty days of recovery. Therefore, this factor may be associated with the drastic reduction in adipose tissue mass following sleep deprivation.

It is well established that PSD modulates levels of cytokines in the serum $[7,10,31]$. The effects on circulating levels of IL-6 after sleep deprivation are controversial. Studies have demonstrated that this cytokine can be elevated [6,32], decreased [10,33] or not measurably changed after sleep deprivation [31,34]. This conflict may in part be related to the dual pro- and anti-inflammatory roles of IL-6.

Our findings demonstrated that IL- 6 was increased in RPAT but not altered in MEAT. This result can be explained by a heterogeneous difference in depots of adipose tissue; MEAT is more stable in the production of immune responses than RPAT [35]. In adipose tissue, IL-6 increases lipolysis, decreases lipase lipoprotein (LPL) activity and increases the mobilisation of fatty acids $[36,37]$. This increase in IL-6 in adipose tissue is similar to responses seen after exhaustive exercise [14], which increases metabolic demands similarly to PSD.

Sleep deprivation did not alter TNF- $\alpha$ in RPAT, but in MEAT this protein was decreased after 96 hours of sleep deprivation. This decrease in TNF- $\alpha$ can be associated with elevated systemic levels of corticosterone. The anti-inflammatory cytokine profile observed in different depots of adipose tissue agreed with a previous report [38] that showed increased IL-10 and decreased TNF- $\alpha$ expression in the brain after PSD. However, the systemic inflammatory profile after PSD is controversial. Studies have found that patients with sleep disturbance show altered circulating concentrations of TNF- $\alpha$, IL$1 \beta$, and IL-1 $[6,39]$. However, other studies have failed to detect changes in circulating levels of IL-6 $[31,34]$ and TNF- $\alpha$ [6] in relation to sleep deprivation. An important site of cytokine production includes monocytes. Lange et al. [39] showed that PSD influenced cells toward a Type 2 immune response. This abolishment of a Type 1 response and increase in Type 2 was associated with increased cortisol levels. Our results suggest that the increase in corticosterone levels up-regulates IL-6 but down-regulates TNF- $\alpha$.

Sleep deprivation causes metabolic alterations with increases in energetic metabolism associated with anorexia, which can cause body weight loss. Therefore,, decreases in lipid serum, increases in lipolysis and decreases in adipose tissue depots are found in PSD rats. 
In conclusion, adipose tissue is affected by sleep deprivation. Beyond loss of adipose tissue mass, sleep deprivation increases cytokine production primarily of anti-inflammatory molecules but also of lipolytic cytokines such as IL- 6 . In MEAT, TNF- $\alpha$ was decreased after sleep deprivation, demonstrating that PSD induces an inhibition in pro-inflammatory response in this tissue as well.

\section{Conflicts of interests}

We declare that there are no conflicts of interest (including financial and other relationships) for each author.

\section{Acknowledgements}

We would like to thank funding sources: 2008/03533-1 from the FAPESP, CEPE, CEPID-Sono, CNPq, AFIP, CAPES and CEMSA.

\section{Author details}

'Departmento de Fisiologia da Nutrição, Universidade Federal de São Paulo (UNIFESP)-São Paulo/SP, Brazil. ${ }^{2}$ Departmento de Psicobiologia, Universidade Federal de São Paulo (UNIFESP) - São Paulo/SP, Brazil. ${ }^{3}$ Associação de Suporte da Psicofarmacologia (AFIP), São Paulo/SP, Brazil. ${ }^{4}$ Departmento de Biociências, Universidade Federal de São Paulo (UNIFESP), Baixada Santista Campus, São Paulo/SP, Brazil.

\section{Authors' contributions}

$J C R$, FSL, DPV, CAC, LMO, GDP, ST, CMON, RVTS and MTM participed the sample collected, assess samples, design of the study and performed the statistical analysis, and writing of paper. All authors read and approved the final manuscript

Received: 24 June 2010 Accepted: 30 October 2010

Published: 30 October 2010

\section{References}

1. Everson CA, Bergmann BM, Rechtschaffen A: Sleep deprivation in the rat: III. Total sleep deprivation. Sleep 1989, 12:13-21.

2. Koban M, Swinson KL: Chronic REM-sleep deprivation of rats elevates metabolic rate and increases UCP1 gene expression in brown adipose tissue. Am J Physiol Endocrinol Metab 2005, 289:E68-74.

3. Rechtschaffen A, Bergmann BM: Sleep deprivation in the rat: an update of the 1989 paper. Sleep 2002, 25:18-24.

4. Everson CA, Crowley WR: Reductions in circulating anabolic hormones induced by sustained sleep deprivation in rats. Am J Physiol Endocrinol Metab 2004, 286:E1060-70.

5. Antunes IB, Andersen ML, Alvarenga TA, Tufik S: Effects of paradoxical sleep deprivation on blood parameters associated with cardiovascular risk in intact and ovariectomized rats compared with male rats. Behav Brain Res 2007, 176:187-92.

6. Shearer WT, Reuben JM, Mullington JM, Price NJ, Lee BN, Smith EO, Szuba MP, Van Dongen HP, Dinges DF: Soluble TNF-alpha receptor 1 and IL-6 plasma levels in humans subjected to the sleep deprivation model of spaceflight. J Allergy Clin Immunol 2001, 107:165-70.

7. Yehuda S, Sredni B, Carrasso RL, Kenigsbuch-Sredni D: REM sleep deprivation in rats results in inflammation and interleukin-17 elevation. $J$ Interferon Cytokine Res 2009, 29:393-8.

8. Patel SR, Zhu X, Storfer-Isser A, Mehra R, Jenny NS, Tracy R, Redline S: Sleep duration and biomarkers of inflammation. Sleep 2009, 32:200-4.

9. Haack M, Kraus T, Schuld A, Dalal M, Koethe D, Pollmächer T: Diurnal variations of interleukin-6 plasma levels are confounded by blood drawing procedures. Psychoneuroendocrinology 2002, 27:921-31.

10. Frey DJ, Fleshner M, Wright KP Jr: The effects of 40 hours of total sleep deprivation on inflammatory markers in healthy young adults. Brain Behav Immun 2007, 21:1050-7.

11. Irwin MR, Wang M, Ribeiro D, Cho HJ, Olmstead R, Breen EC, MartinezMaza O, Cole S: Sleep loss activates cellular inflammatory signaling. Biol Psychiatry 2008, 64:538-40.
12. Bierhaus A, Wolf J, Andrassy M, Rohleder N, Humpert PM, Petrov D, Ferstl R, von Eynatten $M$, Wendt $T$, Rudofsky $G$, Joswig M, Morcos $M$, Schwaninger M, McEwen B, Kirschbaum C, Nawroth PP: A mechanism converting psychosocial stress into mononuclear cell activation. Proc Natl Acad Sci USA 2003, 100:1920-5.

13. Lira FS, Rosa JC, Yamashita AS, Koyama CH, Batista ML Jr, Seelaender M: Endurance training induces depot-specific changes in IL-10/TNF-alpha ratio in rat adipose tissue. Cytokine 2009, 45:80-5.

14. Rosa Neto JC, Lira FS, Oyama LM, Zanchi NE, Yamashita AS, Batista ML Jr. Oller do Nascimento CM, Seelaender M: Exhaustive exercise causes an anti-inflammatory effect in skeletal muscle and a pro-inflammatory effect in adipose tissue in rats. Eur J Appl Physiol 2009, 106:697-704.

15. Gesta S, Blüher M, Yamamoto Y, Norris AW, Berndt J, Kralisch S, Boucher J, Lewis C, Kahn CR: Evidence for a role of developmental genes in the origin of obesity and body fat distribution. Proc Natl Acad Sci USA 2006, 103:6676-81

16. Lafontan M, Berlan M: Do regional differences in adipocyte biology provide new pathophysiological insights? Trends Pharmacol Sci 2003, 24:276-83.

17. Vohl MC, Sladek R, Robitaille J, Gurd S, Marceau P, Richard D, Hudson TJ, Tchernof A: A survey of genes differentially expressed in subcutaneous and visceral adipose tissue in men. Obes Res 2004, 12:1217-22.

18. Mohamed-Ali V, Flower L, Sethi J, Hotamisligil G, Gray R, Humphries SE, York DA, Pinkney J: Beta-adrenergic regulation of IL-6 release from adipose tissue: in vivo and in vitro studies. J Clin Endocrinol Metab 2001, 86:5864-9.

19. Friedewald T, Levy Rl, Frederickson DS: Estimation of the concentration of low-density lipoprotein cholesterol in plasma, without use of the preparative ultracentrifuge. Clin Chem 1972, 18:499-502.

20. Folch J, Lees M, Sloane Stanley GH: A simple method for the isolation and purification of total lipides from animal tissues. J Biol Chem 1957, 226:497-509

21. Crispim CA, Zalcman I, Dáttilo M, Padilha HG, Edwards B, Waterhouse J, Tufik S, de Mello MT: The influence of sleep and sleep loss upon food intake and metabolism. Nutr Res Rev 2007, 20:195-212.

22. Li S, Shin HJ, Ding EL, van Dam RM: Adiponectin levels and risk of type 2 diabetes: a systematic review and meta-analysis. JAMA 2009, 302:179-88.

23. de Mattos $A B$, Pinto MJ, Oliveira C, Biz C, Ribeiro EB, do Nascimento CM, Andersen ML, Tufik S, Oyama LM: Dietary fish oil did not prevent sleep deprived rats from a reduction in adipose tissue adiponectin gene expression. Lipids Health Dis 2008, 7:43-8.

24. Martins PJ, D'Almeida V, Nobrega JN, Tufik S: A reassessment of the hyperphagia/weight-loss paradox during sleep deprivation. Sleep 2006, 29:1233-8.

25. Nakamura K, Shimai S, Kikuchi S, Tominaga K, Takahashi H, Tanaka M, Nakano S, Motohashi Y, Nakadaira H, Yamamoto M: Shift work and risk factors for coronary heart disease in Japanese blue-collar workers: serum lipids and anthropometric characteristics. Occup Med (Lond) 1997, 47:142-6.

26. Patchev V, Felszeghy K, Koranyi L: Neuroendocrine and neurochemical consequences of long-term sleep deprivation in rats: similarities to some features of depression. Homeost Health Dis 1991, 33:97-108.

27. Mullington JM, Chan JL, Van Dongen HP, Szuba MP, Samaras J, Price NJ Meier-Ewert HK, Dinges DF, Mantzoros CS: Sleep loss reduces diurnal rhythm amplitude of leptin in healthy men. J Neuroendocrinol 2003, 15:851-4.

28. Spiegel K, Tasali E, Penev P, Van Cauter E: Brief communication: Sleep curtailment in healthy young men is associated with decreased leptin levels, elevated ghrelin levels, and increased hunger and appetite. Ann Intern Med 2004, 141:846-50.

29. Taheri S, Lin L, Austin D, Young T, Mignot E: Short sleep duration is associated with reduced leptin, elevated ghrelin, and increased body mass index. PLoS Med 2004, 1:e62.

30. Bodosi B, Gardi J, Hajdu I, Szentirmai E, Obal F Jr, Krueger JM: Rhythms of ghrelin, leptin, and sleep in rats: effects of the normal diurnal cycle, restricted feeding, and sleep deprivation. Am J Physiol Regul Integr Comp Physiol 2004, 287:1071-9.

31. Dinges DF, Douglas SD, Hamarman S, augg L, Kapoor S: Sleep deprivation and human immune function. Adv Neuroimmunol 1995, 5:97-110

32. Vgontzas AN, Papanicolaou DA, Bixler EO, Lotsikas A, Zachman K, Kales A, Prolo P, Wong ML, Licinio J, Gold PW, Hermida RC, Mastorakos G, 
Chrousos GP: Circadian interleukin-6 secretion and quantity and depth of sleep. J Clin Endocrinol Metab 1999, 184:2603-7.

33. Haack M, Sanchez E, Mullington JM: Elevated inflammatory markers in response to prolonged sleep restriction are associated with increased pain experience in healthy volunteers. Sleep 2007, 30:1145-52.

34. Born J, Lange T, Hansen K, Mölle M, Fehm HL: Effects of sleep and circadian rhythm on human circulating immune cells. J Immunol 1997. 158:4454-64.

35. Trayhurn P, Bing C, Wood IS: Adipose tissue and adipokines energy regulation from the human perspective. J Nutr 2006, 136:1935-9,

36. Greenberg AS, Nordan RP, McIntosh J, Calvo JC, Scow RO, Jablons D: Interleukin 6 reduces lipoprotein lipase activity in adipose tissue of mice in vivo and in 3T3-L1 adipocytes: a possible role for interleukin 6 in cancer cachexia. Cancer Res 1992, 52:4113-6.

37. Porter MH, Cutchins A, Fine JB: Effects of TNF-alpha on glucose metabolism and lipolysis in adipose tissue and isolated fat-cell preparations. J Lab Clin Med 2002, 139:140-6.

38. Weil ZM, Norman GJ, Karelina K, Morris JS, Barker JM, Su AJ, Walton JC, Bohinc S, Nelson RJ, DeVries AC: Sleep deprivation attenuates inflammatory responses and ischemic cell death. Exp Neurol 2009, 218:129-36.

39. Lange T, Dimitrov S, Fehm HL, Born J: Sleep-like concentrations of growth hormone and cortisol modulate type1 and type2 in-vitro cytokine production in human T cells. Int Immunopharmacol 2006, 6:216-25.

\section{doi:10.1186/1476-511X-9-125}

Cite this article as: Rosa Neto et al:: Sleep deprivation affects

inflammatory marker expression in adipose tissue. Lipids in Health and

Disease 2010 9:125.

\section{Submit your next manuscript to BioMed Central and take full advantage of:}

- Convenient online submission

- Thorough peer review

- No space constraints or color figure charges

- Immediate publication on acceptance

- Inclusion in PubMed, CAS, Scopus and Google Scholar

- Research which is freely available for redistribution

Submit your manuscript at www.biomedcentral.com/submit 